\title{
The Effect of Financial Conditions and Audit Opinions on Local Government Performance
}

\author{
Handoko Arwi Hasthoro (Author) \\ Accounting Departement \\ Faculty of Economics and Business, \\ Janabadra University \\ Yogyakarta, Indonesia. \\ handoko_arwi@janabadra.ac.id
}

\author{
Yanuar Saksono (Author) \\ Management Departement \\ Faculty of Economics and Business, \\ Janabadra University Yogyakarta \\ Indonesia \\ yanuarsaksono@yahoo.com
}

\author{
Nining Widiyanti \\ Management Departement \\ Faculty of Economics and Business, \\ Janabadra University \\ Yogyakarta, Indonesia. \\ nining.wid@janabadra.ac.id
}

\begin{abstract}
This study aims to determine the effect of financial conditions and audit opinion on the performance of local governments in Indonesia. Financial condition is proxied by financial flexibility and audit opinion is measured using the opinion issued by the Supreme Audit Agency (BPK). The Regional Government Performance Variable is measured by the performance evaluation score of regional government administration made by the Ministry of Home Affairs of the Republic of Indonesia in 2018. Thirty-three provincial governments whose financial reports have been audited in 2018 will be used as samples. The method for testing the effect uses multiple linear regression with a probability value of $5 \%$. The test results show that financial conditions have a positive effect on local government performance with a p-value of $\mathbf{0 . 0 8 5 3}$ (significant at the $10 \%$ level). Audit opinion also has a positive effect on local government performance with a p-value of 0.0090 (significant at the $5 \%$ level). This proves that a good financial condition accompanied by good financial management will be able to improve the performance of local governments.
\end{abstract}

Keywords: performance, local government, financial condition, audit opinions

\section{INTRODUCTION}

Regional autonomy in Indonesia applies based on Law No. 32/2004 which was revised to No. 23/2014 on Regional Government. This law clearly separates the functions of the regional government (executive) and the functions of the Regional People's Representative Council (legislative). The transfer of government authority by the government to autonomous regions to regulate and manage government affairs is called decentralization. The granting of regional autonomy is reflected in the Minister of Home Affairs Regulation (Permendagri) No. 13/2006 which has been enhanced by Permendagri No. 59/2007 affirms that regional governments have the authority to determine the allocation of resources into spending by adhering to the principles of compliance, needs and regional capacities. This makes it a challenge for each local government to be able to manage their resources effectively and efficiently.

In accordance with law number 32 of 2004 concerning regional government, regional governments are given broad authority in carrying out all government affairs ranging from planning, implementation, supervision, control and evaluation except the authority in the fields of foreign policy, defense and security, justice, monetary, fiscal, religious and other authorities stipulated by government regulations. Granting regional autonomy rights to regional governments to determine their own regional revenue and expenditure budgets (APBD) according to regional needs and potential. Regional income and expenditure budgets that are set out in the form of regional government financial policies are one of the triggers for economic growth in a region (Mardiasmo 2009).

Political and social dynamics have demanded better governance (good government governance or good public governance). Public governance focuses on how public policies are implemented and public services are carried out (Osborne 2010), which concerns behavior and contributions to government performance (Hill and Lynn Jr 2004). Transparency in the regional financial management process in the era of autonomy policy requires a pattern of public accountability through the development of a government accounting system to provide opportunities for increasing the provision of reliable and accurate information and is oriented towards increasing performance benchmarks in providing maximum public services, and is an accountability process stewardship and accountability process), managerial and management control elements in local government.

In Indonesia, good public governance (GPG) is needed in order to achieve national goals, namely protecting the entire Indonesian nation and all Indonesian blood, and to promote public welfare, educate the nation's life, and participate in maintaining world order based on state sovereignty, eternal peace and social justice ( KNKG 2010). To achieve this goal, a healthy and highly competitive country that is capable of creating added value in a sustainable manner through responsible resource management must be created so that the credibility of the state is built both nationally and in international relations.

The performance of local governments, which are considered still far from expectations, leaves serious homework for regional heads and the central government. Public assessment of the success and failure of government agencies in carrying out the mandate given to them shows the hope and public concern that must be responded to. However, community expectations of local government performance and what government managers and officials do are often different. This means that there is an expectation gap which can lead to disharmony between government agencies and 
direct users from society. Akbar, Pilcher, and Perrin (2012) conducted a study using Partial Least Square to investigate the use of performance measurement systems by local governments in Indonesia. The result is that local governments develop performance indicators more to comply with regulations than to make organizations more effective and efficient in public services.

Expectation gap is a gap that occurs due to differences between people's expectations and what actually guides the quality of management of an organization that provides public services (Mardiasmo 2009). This is a result of the absence of a formal performance measurement system that can inform the success rate of a government agency. In terms of performance, relatively little is known about measuring public sector performance in developing country contexts (Mimba, Helden and Tillema 2007). An entity, including a government entity, needs to recognize signs of bankruptcy and make various remedial efforts in order to increase revenue to prevent potential bankruptcy (Syurmita 2014). To find out the financial health condition of an entity, it is necessary to carry out a financial health analysis. The results of this financial ratio analysis are then used as benchmarks in assessing the health of regional finances as a measure of the level of independence of an area.

Research in the field of public sector accounting in Indonesia has examined many issues of local government performance, both financial and non-financial performance. However, relatively few have examined the financial condition of local governments. Specific research on the financial condition of local governments has been conducted by Ritonga, Clark, and Wickremasinghe (2012), Hasthoro and Septianto (2015), Hasthoro, Sarnowo, and Nurwiyanta (2016). The opportunity to conduct further research is to examine the variables of financial condition and accounting performance of local governments in Indonesia. This research will try to prove empirically whether local governments with good financial conditions also have good performance. Can good accounting performance (audit opinion) affect local government performance?

\section{LITERATURE REVIEW}

\section{A. Local Government Performance}

Government performance is the focus of attention both by government officials and other stakeholders. This is because the issues surrounding government financial management are always interesting to highlight for various interests, especially political aspects. In the perspective of agency theory put forward by Jensen \& Meckling (1976), local government is like an agent who carries the mandate of the people / people's representatives as the principal. So that local governments must show good performance in government administration and public services. Jones \& Pendlebury (2010) stated that government performance is multidimensional, so there is no single indicator that can be used to show comprehensive performance. Furthermore, there are two elements of factors that influence the performance of government organizations, namely elements that are beyond government control (demographics, environment, etc.) and elements that can be controlled by the government (allocation of funds, determination of the number of personnel, and others).

Performance is the level of achievement of the implementation of an activity or policy in realizing the goals, objectives, mission and vision of the organization which are contained in the strategic planning of an organization (Mahmudi 2010). The term performance is used to describe the achievement or level of success of an individual or group. Performance can be determined because the individual or group has predetermined success criteria. Organizational performance can be known if there are certain clear measurements, so that a performance measurement is needed. Performance measurement is a process of assessing the progress of work against predetermined goals and objectives, including information on the efficient use of resources in producing goods and services, the quality of goods and services (how well goods and services are delivered to customers and to what extent customers are satisfied), the results of activities are compared with the intended intent and the effectiveness of the action in achieving the goal (Fenwick and Miller 2012).

\section{B. Financial Conditions}

Financial management is a way of regarding an organization's ability to solve its financial problems, which include cash problems, budget problems, long-term obligations, and service problems (Wang, Dennis, and Tu 2007). According to Law No. 23/2014 Regional Financial Management (management) is all activities that include planning, implementation, administration, reporting, accountability and supervision of regional finances. Financial management is an effort to create good financial conditions. Financial conditions indicate health which greatly affects the movement of government organizations in carrying out predetermined work programs. This is a consequence of implementing work programs that always require funds. Regional autonomy allows local governments to explore the financial potential of their respective regions and has great authority in managing finances. Good financial health enables local governments to carry out their work programs well as well.

Ritonga, Clark, and Wickremasinghe (2012) try to conceptualize the definition of a healthy local government financial condition in Indonesia. The concept includes the assessment of local government financial conditions, namely: short-term solvency, budgetary solvency, long-term solvency, financial flexibility, financial independence, and service level solvency. Thus, the definition of financial conditions in local government according to Ritonga, Clark, and Wickremasinghe (2012) is the financial capacity of local governments to fulfill their obligations, to anticipate unexpected events, and to use funds effectively and efficiently. Syurmita (2014) states that if funds are not managed properly it will cause financial distress. The ratios to assess the financial condition of local governments are based on the information presented in the financial reports of local governments which are prepared based on government accounting standards. Local governments in Indonesia are required to use government accounting standards as stipulated in Government Regulation No. 71/2010. 
The determinants of local government performance are several variables. Fenwick and Miller (2012) prove that there is an effect of changing political management on the performance of local governments in England. In Indonesia, Hasthoro (2014) found that statistically the size of the region (size), the population, and the corruption perception index affect the financial performance of local governments. Furthermore, Hasthoro and Septianto (2015) found that there was an effect of financial conditions on the performance of district and city governments in Central Java and Yogyakarta. Financial conditions also affect the public governance of provincial governments in Indonesia (Hasthoro, Sarnowo, Nurwiyanta 2016). Other findings by Hasthoro and Sunardi (2016) show that community participation and legal culture affect the performance of 50 local governments in Indonesia. Based on the description above, the hypotheses that can be developed are:

H1: Financial conditions have a positive effect on local government performance

\section{Audit Opinions}

Audit opinion is the auditor's opinion regarding the financial statements of a company or agency. The auditor conducts an independent examination of the financial statements so that the reliability of the company or agency's financial statements can be accounted for. Jones and Bates (1990) state that public accountants / auditors are generally tasked with providing assurance on the fairness of financial statements prepared and published by corporate and government management.

According to Auliyana (2017) local governments that accept unqualified opinion (WTP) and unqualified opinion (WDP) in explanatory language tend to be more prestigious than other opinions. So that leaders or regional heads tend to pursue the WTP opinion in any way, even though some of them ignore the applicable rules and regulations. Local governments also have an interest in immediately reporting their financial reports as a demonstration of the economic performance of their institutions. Aprila, Fachruzzaman, and Pratiwi (2017) prove that district / city governments that obtain WTP audit opinions tend not to experience audit delays, which means that the submission of their financial statements does not experience delays. Parker, Schmitz, and Jacobs (2020) found that in Australia the performance of the public sector being audited is strongly influenced by the behavior and logic of auditors and those being audited. Based on the description above, the hypotheses that can be developed are:

H2: Audit opinion has a positive effect on local government performance

\section{RESEARCH METHOD}

\section{A. Population and Sample}

The population in this study is the provincial government in Indonesia and all of them will be sampled using the census sampling method.

\section{B. Operational Definition and Variable Measurement}

- The dependent variable in this study is the Performance of Local Government which is proxied by the performance score by the Ministry of Home Affairs of the Republic of Indonesia in 2018.

- The first independent variable in this study is the financial condition proxied by the financial flexibility ratio (Ritonga, Clark, and Wickremasinghe 2012). Financial condition data is 2018. The second independent variable in this study is the Accounting Performance with an Audit Opinion proxy issued by the Supreme Audit Agency. The measurement for this variable is using serial data. Unqualified Opinion is given a score of 4, Fair Opinion with Explanation is given a score of 3, Unfair Opinion is given a score of 2 and Not Giving Opinion is given a score of 0. Data on Audit Opinion is 2018.

\section{Equations}

Hypothesis testing is done by using Multiple Regression Test. The formulation or formulation is as follows (Gujarati and Porter 2010):

$\mathrm{Y}=\beta 0+\beta 1 \mathrm{X} 1+\beta 2 \mathrm{X} 2+\varepsilon$

Where:

$\mathrm{Y}=$ Local Government Performance

$\beta 0=$ Constant $\beta 1, \ldots \beta 2=$ Regression Coefficient

$\mathrm{X} 1$ = Financial Condition (Financial Flexibility)

$\mathrm{X} 2=$ Audit Opinion; $\varepsilon=$ error

\section{RESULT AND DISCUSSION}

Result of hypothesis testing are discussion as follow.

\section{A. Descriptive statistics}

In this descriptive statistics section, the data for each variable will be presented in the form of a minimum, maximum, mean, and standard deviation as follows:

TABLE I. Statistik Deskriptif

\begin{tabular}{c|c|c|c|c|c}
\hline Var & N & Minimum & Maksimum & Mean & $\begin{array}{c}\text { Standar } \\
\text { Deviasi }\end{array}$ \\
\hline KK & 33 & 0,263 & 0,533 & 0,348 & 0,076 \\
\hline OA & 33 & 3,000 & 4,000 & 3,939 & 0,242 \\
\hline KI & 33 & 2,308 & 3,326 & 2,821 & 0,244 \\
\hline
\end{tabular}

The purpose of implementing regional autonomy is so that local governments can reduce dependence and increase independence from the central government. This goal is achieved when the local government can optimize its performance. This study uses the performance evaluation score of local government administration (EKPPD) as a proxy for local government performance. The measure used is a score between 0 and 4 , where the higher the score, the local government is said to have the better performance. Descriptive statistics show, with a sample of 33, the mean (mean) performance of the provincial government is 2.821 which means that it is at a high status level. The lowest EKPPD score was 2.308 (Papua Province) and the highest was 3.326 (East Java Province). 
The financial condition variable is a form of the financial condition of an institution. This study uses the financial flexibility ratio as formulated by Ritonga et al. (2012) to describe the financial condition of the provincial government. The higher the ratio, the more flexible it is in dealing with financial problems at any time. Descriptive statistics show, with a sample of 33, the mean (mean) financial condition of the provincial government is 0.348 . The mean value indicates that financial conditions are not yet flexible because they are still below 0.500 or $50 \%$. The worst financial condition is the Provincial Government of East Nusa Tenggara with a ratio of $26.3 \%(0.263)$. Meanwhile, the best financial condition is the Provincial Government of DKI Jakarta with a ratio of $53.3 \%$ (0.533). Financial management must be better improved by taking steps to save and efficient regional spending.

Audit opinion is a statement of opinion from the auditor to show the fairness of an institution's financial statements which are prepared based on applicable accounting standards. Opinions consist of 4 levels, namely: Unqualified, Fair with Explanation, Unfair, and Disclaimer (not expressing an opinion). Descriptive statistics show, with a sample of 33, the mean (mean) provincial government audit opinion is 3,939 . This mean value indicates that the audit opinion of the provincial government is good, almost close to 4 , which means that most of them receive unqualified opinion.

\section{B. Result of Research}

Hypothesis testing uses multiple linear regression method with cross section data characteristics. The purpose of hypothesis testing is to empirically prove the effect of the independent variable on the dependent variable. The test results using multiple linear regression can be seen from the following variables:

TABLE 2. Hasil Penelitian

\begin{tabular}{lccc}
\hline \multicolumn{1}{c}{ Variabel } & Koefisien & T & Sig \\
\hline (Constant) & 1,964 & 11,008 & 4,658 \\
\hline Kondisi Keuangan & 0,940 & 1,779 & 0,085 \\
\hline Opini Audit & 0,167 & 2,791 & 0,009 \\
\hline$R$ Square & 0,444 & & \\
\hline Adjusted $R$-Square & 0,407 & & \\
F & 12,023 & & \\
\hline Sig & $0.000^{\mathrm{a}}$ & & \\
\hline
\end{tabular}

The statistical test results show the significance value of $F$ is 0.000 smaller than the p-value of 0.05 , which means that simultaneously (together) all independent variables, namely financial conditions and audit opinion have a significant effect on local government performance (dependent variable).

The next test is a partial test ( $t$ test). The purpose of this test is to prove empirically whether the independent variable has an influence on the dependent variable individually. The results of statistical calculations on partial / individual testing show that the financial condition variable is significant at the p-value 0.10 with a significance value of 0.085 . Then the audit opinion variable is significant at the $p$-value level of 0.05 with a significance value of 0.009 , which means that the two variables individually have a significant effect on the performance of local governments.

\section{Discussion}

Based on the statistical calculations in table 4.2, the regression equation model, with constant values and regression coefficients, can be written as follows:

$\mathrm{KPDA}=1,964+0,940 \mathrm{KK}+0.167 \mathrm{OA}$

The constant in the research model is 1.964 , which indicates that local government performance is fixed at 1.964. The regression coefficient value of the financial condition variable is 0.940 , which means that if this variable increases by one unit, the local government performance will increase by 0.940 , ceteris paribus. The results of individual testing show that the influence of the financial condition variable is real and shows a positive direction on regional financial performance with a significance value of 0.085 (significant at p-value 0.10 ), so that the first hypothesis (H1) in this study is accepted. This means that the better the financial condition, the local government will succeed in improving its performance. The results in this study prove the findings of Ritonga et.al. (2012) and Hasthoro and Septianto (2015) state that good financial conditions affect local governments in an effort to improve local government performance. Local governments that have abundant financial resources have become more flexible and routine in providing services to the community by funding predetermined programs. Good service will generate public trust in the government so that it can increase compliance with paying taxes and fees as a source of income for local governments (Syurmita 2014).

The audit opinion variable in the research model above has a regression coefficient value of 0.167 which means that if this variable increases by one unit, the performance of the local government will increase by 0.167 , ceteris paribus. The results of individual testing show that the effect of the audit opinion variable is real and shows a positive direction on local government performance with a significance value of 0.000 (significant at p-value 0.05), so that the first hypothesis ( $\mathrm{H} 2)$ in this study is accepted. This means that the better the audit opinion, then this will give a boost to local government performance improvement. Audit opinion has an important psychological effect to motivate government officials to achieve institutional performance (Hasthoro and Ardiansyah 2019). In the context of audit delay, audit opinion has a positive effect on audit delay of district / city governments throughout Indonesia (Aprila and Pratiwi 2017).

\section{CONCLUSION}

This study aims to determine the effect of financial conditions and audit opinion on the performance of local (provincial) governments in Indonesia. The study used data from 33 provinces in 2018. The results showed that financial conditions had a positive effect on the performance of local (provincial) governments at the p-value level of $10 \%$. However, the government, which has adequate funds, will be free to create programs for performance achievement. The audit opinion variable also has a positive effect on the performance of local (provincial) governments at the p-value 
level of 5\%. A good audit opinion will motivate employees to achieve predetermined performance targets.

There are several limitations in making conclusions in this study, namely the relatively small number of data used is 33 . Further research is suggested to be able to test with the same variables on the subject of district and city government in Indonesia, which is about 500. With a large number of subjects, the results of the study can used as a reference for the discussion of the variables used.

\section{ACKNOWLEDGMENT}

The Authors would like to thank for funding this research by the University of Janabadra Yogyakarta so that it can be completed and can be presented in the seminar on the 3rd ICOBAME.

\section{REFERENCES}

[1] Akbar, R., R. Pilcher, dan B. Perrin. 2012. Performance Measurement in Indonesia: The Case of Local Government. Pacific Accounting Review 24 (3): 262-291.

[2] Aprila, N., Fachruzzaman, dan D.S. Pratiwi. 2017. Pengaruh Opini Audit dan Kualitas Auditor Terhadap Audit Delay pada Pemerintah Kabupaten/Kota di Indonesia. Jurnal Akuntansi 7 (3): 75-86.

[3] Auliyana, E. 2017. Studi Kasus Fenomenologi Atas Opini Audit WTP di Kalangan Pejabat Pemerintah Provinsi Jawa Timur. Jurnal Akuntansi Aktual 4: 22-33

[4] Azhar, M.K.S. 2008. Analisis Kinerja Keuangan Pemerintah Daerah Kabupaten/Kota Sebelum dan Setelah Otonomi Daerah. (Tesis. Program Magister Akuntansi Sekolah Pascasarjana Universitas Sumatera Utara, Medan).

[5] Bovaird, T., dan E. Loffler. 2003. Understanding Public Management and Governance. in Bovaird, T., dan E. Loffler. (Eds). Public Management and Governance. London, UK: Routledge.

[6] Fenwick, J., dan K.J. Miller. 2012. Political Management and Local Performance: A Testing Relationship? International Journal of Public Sector Management 25 (3): 221-230.

[7] Gujarati, D.N., dan D.C. Porter.2010. Dasar-Dasar Ekonometrika. Edisi ke-5. Jakarta: Salemba Empat

[8] Hasthoro, H.A. 2014. Pengaruh Karakteristik Pemerintah Daerah dan Indeks Persepsi Korupsi Terhadap Kinerja Keuangan Daerah. (Tesis. Program Pascasarjana Universitas Sebelas Maret, Surakarta).

[9] Hasthoro, H.A., dan Ardiansyah. 2019. Perbedaan Kinerja Akuntansi antara Pemerintah Kota dan Kabupaten di Indonesia. Laporan penelitian tidak dipublikasikan.
[10] Hasthoro, H.A., dan Sunardi. 2014. Public Governance dan Kinerja Keuangan Pemerintah Daerah di Indonesia. Prosiding $3^{\text {rd }}$ Economics \& Business Research Festival, Fakultas Ekonomi dan Bisnis Universitas Kristen Satya Wacana Salatiga, Indonesia.

[11] Hasthoro, H.A., dan W. Septianto. 2015. Pengaruh Kondisi Keuangan pada Kinerja Penyelenggaraan Pemerintah Daerah di Indonesia. Prosiding $4^{\text {th }}$ Economics \& Business Research Festival, Fakultas Ekonomi dan Bisnis Universitas Kristen Satya Wacana Salatiga, Indonesia.

[12] Hasthoro, H.A., H. Sarnowo, Nurwiyanta. 2016. The impact of financial condition on public governance among provincial government in Indonesia. Proceeding $1^{\text {st }}$ ICOBAME: International Conferences on Business, Accounting, Management, and Economics, Fakultas Ekonomi \& Bisnis Universitas STIKUBANK Semarang, Indonesia.

[13] Hill, C.J., dan L.E. Lynn Jr. 2004. Governance and Public Management an Introduction. Journal of Policy Analysis and Management 23 (1): 3 11.

[14] Jensen, M.C., and W.H. Meckling. 1976. Theory of Firm: Managerial Behavior, Agency Costs, and Owrnership Structure. Journal of Financial Economics 3: 305-360.

[15] Jones, P.C., and J.G. Bates. 1990. Public Sector Auditing: Practical Techniques for an Integrated Approach. First Edition. Chapman and Hall, London, UK

[16] Jones, R. and M. Pendlebury. 2010. Public Sector Accounting. Sixth Edition. Pearson Education (Prentice Hall)

[17] Mahmudi. 2010. Manajemen Kinerja Sektor Publik. Edisi Ke-2. Yogyakarta: UPP STIM YKPN

[18] Mardiasmo. 2009. Akuntansi Sektor Publik. Edisi Ke-4. Yogyakarta: Penerbit ANDI.

[19] Mimba, N.P.S.H., G.J. Helden, dan S. Tillema. 2007. Public Sector Performance Measurement in Developing Countries: A Literature Review and Research Agenda. Journal of Accounting \& Organizational Change 3 (3): 192-208.

[20] Osborne, S.P. 2010. The New Public Governance: A Suitable Case for Treatment? in Osborne, S.P. (Ed). The New Public Governance? Emerging Perspectives on the Theory and Practice of Public Governance. London, UK: Routledge.

[21] Peraturan Pemerintah No 3 Tahun 2007 Tentang Laporan Penyelenggaraan Pemerintahan Daerah.

[22] Ritonga, I.T., C. Clark, and G. Wickremasinghe. 2012. Assesing Financial Condition of Local Government in Indonesia: An Exploration. Public and Municipal Finance 1 (2): 37- 50.

[23] Syurmita. 2014. Prediksi Financial Distress Pemerintah Daerah Kabupaten/Kota Di Indonesia. Simposium Nasional Akuntansi XVII: Banjarmasin, Indonesia.

[24] Undang-Undang Republik Indonesia No 23 Tahun 2014 Tentang Pemerintah Daerah. 